\title{
The Impact of Entrepreneurship Education on Entrepreneurial Stimulus and Skills
}

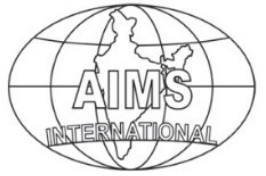

DOI: $10.26573 / 2019.13 .3 .4$

Volume 13, Number 3

September 2019, pp. 197-205

\author{
G. K. S. Nimeshi \\ University of Kelaniya \\ (nimeshis@kln.ac.lk)
}

Entrepreneurship can be defined as the key motorist of development in any country regardless of the rank of the development. Entrepreneurial education can be considered as one of the main steps to motivate people on entrepreneurship. This research paper examines the impact of a leading entrepreneurship education program in Sri Lankan state universities on entrepreneurship skills and motivation of university students. The researcher has selected two universities in the Western province which are offering entrepreneurship degree programs for undergraduates and sample has been selected via simple random sampling technique and the sample size was 96. A self-administered questionnaire was used in the study as the research instrument. To analyze the data, both descriptive and inferential analytical tools were used. The results show that the programs have a significant effect on students' self-assessed entrepreneurial skills and the inclination to become an entrepreneur.

Keywords: Entrepreneurial Motivation, Entrepreneurship Education, Entrepreneurial Skills,

\section{Introduction}

Researches, policy makers, expertise people and all the other responsible parties in all over the world, especially in Sri Lanka believe that more entrepreneurship is required to achieve higher levels of economic growth and innovation. It can be considered as the key motorist of development in any country regardless of the rank of the development. Indeed, empirical research studies also support positive relations between entrepreneurial activity and economic outcomes such as economic growth and innovation. Entrepreneur is a person who seeking profit opportunities and thereby introducing 'new combinations' or innovations. In the economic system, these new combinations are the prime interest cause of development. New entrepreneurial combinations destroy the equilibrium in the economy and create a new equilibrium. It can be called as creative destruction, the theory introduced by Schumpeter. According to him, this is the central point of entrepreneurial growth.

Academics, policy makers and researchers also believe that, the degree of entrepreneurship can be achieved through education. According to the literature, especially it can be reached through entrepreneurship education. Hence, entrepreneurship education programs are promoted and implemented into many of the education systems in the world as well as in Sri Lanka. Today, school curriculums also included entrepreneurship subjects. Especially, in Sri Lankan 
universities, entrepreneurship is becoming very popular domain. Both undergraduate degrees and postgraduate degrees are introducing entrepreneurship subjects. Four conventional universities in Sri Lanka offers entrepreneurship degree programs for undergraduates namely, Bachelor of Business Administration (Special) in Entrepreneurship, Bachelor of Business Management in Entrepreneurship \& Management, Bachelor of Commerce Special Degree in Entrepreneurship, and Bachelor of Science (Special) in Human Entrepreneurship. Those universities are, University of Sri Jayewardenepura, University of Kelaniya, University of Ruhuna and Uwa Wellassa University. This study was carried out in two of those universities namely, University of Kelaniya and University of Sri Jayewardenepura. These particular universities have been offering these degrees for more than six years and they highly facilitate and promote entrepreneurship and entrepreneurship education. Other universities also act as same. Here, policy makers are working on the assumption of "Entrepreneurs can be made" and "they are not fixed personal characteristics". Therefore, every entrepreneurship program is trying to promote entrepreneurship and build entrepreneurs. The main objective of these programs is to teach students to put theory into practice and to understand what entrepreneurship is about. In order to achieve the mentioned objective, there are practical subjects as well. Students are doing real business as the main curriculum activity and thereby students are assumed to gain self-confidence and motivation, become proactive, creative, learn how to work in a team and learn to face failures.

Giving the fact that many universities use the program, insignificant is known about its impact on students' entrepreneurial competencies, skills and intentions. Even today also the program's effectiveness and successfulness has only been evaluated through the appreciation of the parties involved. There are a few solid impact evaluation studies have been conducted so far in Sri Lanka. And the results of those studies also fragmented. The current study starts to fill this gap by evaluating the impact of a leading entrepreneurship education program in Sri Lankan state universities on entrepreneurship skills and motivation of university students.

The remaining part of this paper is organized as follows. Section two presents the literature review. Section three describes the methodology and its identifying assumptions and hypothesis. Section four provides details about the data and furthermore presents and discusses the empirical results. In Section six, the researcher summarizes and concludes, and offers possible explanations for the findings.

\section{Literature Review}

The term entrepreneurship education is used interchangeably with entrepreneurship training and skill acquisition. Conceptually, entrepreneurship education can be refers to as a specialized knowledge that inculcates in learners the traits of risk-taking, innovation, arbitrage and co-ordination of factors of production for the purpose of creating new products or services for new and existing users within human communities (M.Minniti \& M.Levesque, 2008). There is an increasing importance of entrepreneurship education due to the need to prepare students for coping in the contemporary work and living environment.

Entrepreneurship education can be defined in narrower and broader terms. It can be seen as "opportunity recognition, marshalling of resources in the presence of risk, and building a business venture" and as "a collection of formalized teachings that 
informs, trains, and educates anyone interested in business creation, or small business development" (Merle Küttima, et al., 2013). At a broader level entrepreneurship education can be placed in a wider context than business preparing not only "an entrepreneurial person" who may become self-employed and an owner of an enterprise, but also a person who is able to pursue entrepreneurship and innovation as an employee and/or be a person who exhibits "enterprising behaviour" (Merle Küttima, et al., 2013).

Furthermore, the content of entrepreneurship education has to answer to the growing interest and demand. Today the programs seem to focus on new venture creation backed up by options on growing business, financing entrepreneurial businesses, law, networks, family business and social enterprise with business plan playing a dominant role (Gibb, 2002).

Entrepreneurial stimulus and skills have been used in previous studies as a reference to owning a business or becoming self-employed as a set of broader personal orientations, dispositions, desires, or interests that might lead to venture creation, and also as nascent entrepreneurship including those who have only thought about establishing an own business and those who have taken more specific steps towards that (Thompson, 2009).

The previous studies have proved that entrepreneurship education programs contribute to the development of entrepreneurial stimulus and skills. However, the impact of entrepreneurship education programs is different with the content and context of the programs.

According to the study carried out by Hessel Oosterbeek, Mirjam van Praag and Auke Ijsselstein, (2010), entrepreneurship education program has a significantly negative impact on entrepreneurial intentions and a zero impact on entrepreneurial skills. The results of this study are very surprising given the program's objective to develop entrepreneurial skills and affect entrepreneurial intentions of the students exposed to it positively. But, majority of the studies are giving opposite side of the results and they have proved that, entrepreneurship education program has a positive impact on entrepreneurial skills and stimulus (Merle Küttima, et al., 2013; Lüthje, C \& Franke, N, 2003; Peterman, N.E \& Kennedy, J, 2003).

\section{Methodology}

As per the research questions and hypothesis, this study requires a deductive approach since this study deeply examines the causal effects. To address research questions, the study intends to adhere to a sample of undergraduates of Sri Lankan state universities who follow the entrepreneurship degree program as a representation of the population. Given the time frame of the study, researcher carried out a cross-sectional type of quantitative research, aimed at surveying a population of undergraduates in Sri Lanka. This study assesses a sample of undergraduates identified the university as the unit of analysis. The study was carried out in two state universities in Western province which is having entrepreneurship degree program, namely, University of Kelaniya, and University of Sri Jayewardenapura. Both primary and secondary data was used in this study to empirically test those hypotheses. Secondary data are gathered through the provincial councils, central bank reports and other publications. The primary data gathering process of this research study aims to utilize a self-administered questionnaire. To attain those mentioned research questions, the study intends to adhere to a sample of 
undergraduates attached to the state universities in Sri Lanka as a representation of the population. Simple random sampling method was used as the sampling method of the study, and sample consists with 96undergraduates. To evaluate the level of entrepreneurial motivation and entrepreneurial skills of students and to assess the impact of entrepreneurship education level on the level of entrepreneurial motivation and entrepreneurial skills of students, the researcher has adopted tested scales with minor adjustments. The complete questionnaire consists of 04 (four) sections, such as, Demographic factors, entrepreneurship education level, entrepreneurial skills and level of entrepreneurial motivation.

Demographic information is collected in the section "A" in order to develop a profile of the sample. Section B focuses on the respondents $\square$ education level associated with entrepreneurship. Sections $\mathrm{C}$ focuses on the entrepreneurial skills of respondents and Sections D focuses on the entrepreneurial intention/ motivation of respondents, and those two sections are related to the key dependent variables. All these questions were formulated as sentences answered on a seven-point Likertscale, with 1 - "completely disagree" and 7 - "completely agree."

Entrepreneurial traits have been measured by the competency of students (Hessel Oosterbeek, et al., 2010) and the first competency is need for achievement. According to the literature, successful entrepreneurs are having high on need for achievement by determined for performance sufficiently and competing. They build their company with their professional goals in mind. Always they set high target levels to achieve their goals and put in much effort to reach them. Internal locus of control is often the cognitive reason for choosing entrepreneurship. Successful entrepreneurs score high on this competency that reflects independent decision making, the ability to resolve their problems and to bring activities to a successful end on their own. Not with the luck and infinity. The next one is need for power, it can be defined as the need to have control over others to guidance their behavior. Successful entrepreneurs score high on this competency representing that they know what they want and how to influence others to achieve their own goals. Social orientation taken as the next competency and successful entrepreneurs are having the understanding that relationships with others (personal relationships) in the society are required to realize their own ideas. They build these connections easily and they are motivated by professional considerations in their social activities. They set their social needs aside and focus on their business. Next one is self-efficacy, reflects the belief in their own ability. Successful entrepreneurs are usually convinced that they can bring every activity to a successful end with the hard working. Also, they feel that they can control their own success, which does not depend on others. Risk taking propensity is one of the main competencies of successful entrepreneurs and in the Escan reflects both the ability to deal with uncertainty and the willingness of risking to take a loss.

Under the skills of entrepreneurs, the researcher has taken market awareness, creativity and flexibility since they are the most usable skills in the literature (Hessel Oosterbeek, et al., 2010). Creativity can be defined as the use of ideas and imaginations to create something new to the world. The knowledge on market is market awareness and flexibility is the ability to change with the environmental changes and market changes.

The research was carried among 110 undergraduates in state universities, Sri Lanka. In order to check the reliability of the questionnaire, initially, the 
questionnaire was directed to 20 respondents and proved with Cronbach's alpha for the variables of the study. It shows that the answers given by the respondents were highly reliable as the Reliability Coefficient is closer to 1 (One).The researcher collected data from 110 undergraduates in two universities after analyzing and interpreting the data of the pilot study and returned 96 questionnaires out of which, and the effective rate was 87 per cent.

Based on many studies of the determinants of successful entrepreneurship, mainly from psychology and business studies, the so-called Escan has been developed (Driessen, M.P \& Zwart, P.S, 1999; Driessen, 2005; Hessel Oosterbeek, et al., 2010)). The Escan is a validated self-assessment test based on 114 items (Hessel Oosterbeek, et al., 2010). Therefore, this test has been used to measure students' entrepreneurial competencies.

\section{Data Analysis and Testing Hypothesis}

This section begins with describing in some detail of how entrepreneurial traits, skills and intentions have been measured. After that, it explains furthermore how the data were presented as descriptive statistics.

As mentioned in the methodology, the researcher has done a pilot study in order to test the reliability of the study. The following table shows the Cronbach Alpha values of the each and every variable.

Table 1 Reliability Statistics

\begin{tabular}{|l|c|c|}
\hline \multicolumn{1}{|c|}{ Construct } & No. of Items & Cronbach Alpha Values \\
\hline Traits & & \\
\hline Need for Achievement & 06 & 0.722 \\
\hline Locus of Control & 04 & 0.714 \\
\hline Need for power & 04 & 0.665 \\
\hline Social orientation & 08 & 0.610 \\
\hline Self efficacy & 08 & 0.809 \\
\hline Risk Taking Propensity & 05 & 0.659 \\
\hline Skills & & \\
\hline Market awreness & 10 & 0.812 \\
\hline Creativity & 11 & 0.699 \\
\hline Flexibility & 07 & 0.712 \\
\hline Entrepreneurial Intention & 06 & 0.937 \\
\hline Entrepreneurial Education & 18 & 0.765 \\
\hline
\end{tabular}

Based on the above values the researcher has moved to the main analysis of the study. Firstly the researcher has tested whether the data set in lined with outliers, univariate normality and multi collinearity in the study. In order to do the test, the researcher has conducted exploratory analysis in SPSS 20 (Statistical Package for Social Sciences). And as a precautionary step, researchers performed Series Mean function to exclude all the missing values of the data set. Thereafter, the study moved to detecting and handling outliers of the study. In order to do that, mean 
values of all the variables were compared with the respective 5\% trimmed mean values of the variable. However, none of the variable matched with significant deviations among the mean and the trimmed mean. Hence the researcher postulated nonappearance of outliers of the data set. After that, Normality and Multi collinearity were tested and then, autocorrelation was tested and Homoscedasticity was examined by residuals. Finally by using simple regression analysis and correlation analysis, hypothesis were tested. The skewness and kurtosis rule has been used to examine normality and Tolerance and Variance Inflation Factor values of the study has been used to testing for Multicollinearity. Moreover, autocorrelation was tested by Durbin-Watson value and Homoscedasticity was examined by residuals.

To find out whether there is any relationship among the variables, Correlation analyses were done among all the variables. Here, the study shows the correlation between entrepreneurship education and entrepreneurial traits, skills and motivation in Table 01 using the method of correlation coefficient. Specifically, correlation analysis was conducted between the dependent variables 'entrepreneurial traits, skills and motivation' with the independent variable namely 'entrepreneurship education'. According to the correlational values depicted in the Table 01, statistical significant relationship is observed at the surface level.

Table 2 Correlation Coefficient

\begin{tabular}{|l|l|c|c|c|c|}
\hline \multicolumn{7}{|c|}{ Correlations } \\
\hline & $\begin{array}{c}\text { Entrepren } \\
\text { eurship } \\
\text { Education }\end{array}$ & $\begin{array}{c}\text { Entrepreneurial } \\
\text { Skills }\end{array}$ & $\begin{array}{c}\text { Entrepreneurial } \\
\text { Traits }\end{array}$ & Entrepreneurial Intention \\
\hline $\begin{array}{l}\text { Entrepreneurship } \\
\text { Education }\end{array}$ & $\begin{array}{l}\text { Pearson } \\
\text { Correlation }\end{array}$ & 1 & $.876^{* *}$ & $.691^{* *}$ & $.735^{* *}$ \\
\hline $\begin{array}{l}\text { Entrepreneurial } \\
\text { Skills }\end{array}$ & $\begin{array}{l}\text { Pearson } \\
\text { Correlation }\end{array}$ & $.876^{* *}$ & 1 & $.801^{* *}$ & $.766^{* *}$ \\
\hline $\begin{array}{l}\text { Entrepreneurial } \\
\text { Traits }\end{array}$ & $\begin{array}{l}\text { Pearson } \\
\text { Correlation }\end{array}$ & $.691^{* *}$ & $.801^{* *}$ & 1 & $.663^{* *}$ \\
\hline $\begin{array}{l}\text { Entrepreneurial } \\
\text { Intention }\end{array}$ & $\begin{array}{l}\text { Pearson } \\
\text { Correlation }\end{array}$ & $.735^{* *}$ & $.766^{* *}$ & $.663^{* *}$ & 1 \\
\hline
\end{tabular}

**. Correlation is significant at the 0.01

level (1-tailed).

More in detail, it is observed that entrepreneurial skills, traits and intention and entrepreneurship education are associated with a positive relationship suggesting a same direction. And that relationship is statistically significant.

Finally, the regression analysis has done to find out the significant impact or influence of independent variable on the dependent variables. Hence, to identify the significant determinants of entrepreneurial skills, traits and intention of undergraduates and to test the hypotheses stated the researcher used multiple regression analysis.

The analysis of the ordinary least square regression results of the model of the study is shown in Table 03, model summary. It shows the association between the dependent variables, entrepreneurial traits, skills and intention and independent variable, entrepreneurship education of the study shown in Table 04 in the Regression Analysis. Moreover, table 04, confirms the overall model fit of the study suggesting a significant $P$ value which is 0.000 . Therefore, the researcher suggests the $78.6 \%$ impact is in the significant level in the study. 
Moreover, as in the results of table 04, independent variable is statistically significant, (at 5\% level) (0.000). Thus, researcher concluded that, entrepreneurship education is the statistical significance predictor of the entrepreneurial traits, skills and intention of students of the study. And also, positive beta coefficient value of the independent variable mean that an increase of this variable bring about an increasing impact on entrepreneurial traits, skills and intention of students.

In the current study, hypotheses were tested by using multiple regression analysis and the entire hypotheses were accepted and finally the researcher concluded that, entrepreneurship education has a positive impact on entrepreneurial traits, skills and their motivation.

Table 3 Model Summary

\begin{tabular}{|c|c|c|c|c|}
\hline Model & R & R Square & Adjusted R Square & Std. Error of the Estimate \\
\hline 1 & $.794^{\mathrm{a}}$ & .739 & .786 & 26.81312 \\
\hline \multicolumn{2}{|l}{ a. Predictors: (Constant), Education } \\
\hline \multicolumn{4}{l}{ b. Dependent Variables: Entrepreneurial Skills, Traits, Intention } \\
\hline
\end{tabular}

Table 4 ANOVA Table in the Regression Analysis

\begin{tabular}{|c|c|c|c|c|c|c|}
\hline & Model & Sum of Squares & df & Mean Square & $\mathbf{F}$ & Sig. \\
\hline \multirow{3}{*}{1} & Regression & 61205.43 & 7 & 6985.31 & 21.83 & $.000^{\mathrm{b}}$ \\
\hline & Residual & 122381.512 & 165 & 512.98 & & \\
\hline & Total & 162466.012 & 288 & & & \\
\hline \multicolumn{7}{|c|}{ a. Predictors: (Constant), Education } \\
\hline \multicolumn{7}{|c|}{ b. Dependent Variables: Entrepreneurial Skills, Traits, Intention } \\
\hline
\end{tabular}

Table 5 Coefficients Table for the Regression Analysis

\begin{tabular}{|c|c|c|c|c|c|}
\hline \multirow{2}{*}{ Model } & \multicolumn{3}{|c|}{\begin{tabular}{|l|l|} 
Unstandardized Coefficients & Standardized Coefficients \\
\end{tabular}} & \multirow{2}{*}{$\mathbf{t}$} & \multirow{2}{*}{ Sig. } \\
\hline & $\mathrm{B}$ & Std. Error & Beta & & \\
\hline (Constant) & -7.591 & 17.124 & & -4.625 & .750 \\
\hline Education & 1.112 & .500 & .028 & 3.198 & .000 \\
\hline
\end{tabular}

\section{Conclusion and Recommendations}

This research study mainly examines the impact of the leading entrepreneurship education program on entrepreneurial traits, skills and intentions in Sri Lanka. Researcher has selected two state universities in Western Province due to the time limitation. However, researcher explains that the entrepreneurship programs are offering to students with the main objective of increasing entrepreneurial inclination of students. Therefore the study has gone through entrepreneurial intention, skills and traits.

The results show that the program does have the intended result. The effects on students' self-assessed entrepreneurial skills and traits are significant. The effect on entrepreneurial intentions is also significantly positive. This result views are shaping and strengthening the earlier positive outcomes of assessments based on the 
appreciation of the parties involved. But, the results of the current study stands sharp contrast to earlier negative outcomes (eg: Hessel Oosterbeek, et al., 2010).

The results of this study can be related to the fact that, students have obtained more accurate perspectives both on themselves as well as on what it takes to be an entrepreneur. A more realistic self-assessment may have caused the increases in the traits measures among students and it might have caused the slight increases in the entrepreneurial skill levels of program.

The positive impact of the program on the intention to become an entrepreneur can be used to make educational programs and policy makers also can use this knowledge when they are making the policies.

The contribution of the current study is that, it is created new knowledge to the existing literature and in Sri Lanka; very few studies are carried out on entrepreneurship education. There is an increasing importance of entrepreneurs in developing countries like Sri Lanka. Hence, policy makers can pay more attention on entrepreneurship education based on the results.

Currently, only five state universities in Sri Lanka offers entrepreneurship degree programs for undergraduates. It is very important to offer entrepreneurship degree programs by other universities also. In school level curriculum, only very few space is there for entrepreneurship. Schools and universities should bear the first responsibility of entrepreneurship education in a country. We can increase the better adaption to job market requirements by carrying out entrepreneurship education through the educational content and classroom climate. Thus, great efforts should be put on entrepreneurship education and researching the models and content of entrepreneurship education in order to improve entrepreneurship.

Furthermore, Universities and companies need to create entrepreneurship culture and raise entrepreneurship awareness. Students should take the initiative actions to improve their entrepreneurship inclination by strengthening the study and knowledge of entrepreneurship, applying entrepreneurship skills to community activities, and etc.

Meanwhile, this paper also states that, entrepreneurship education as dominant important and justifiable domain.

Finally, when addressing the concern of the implication for the body of knowledge, this study adds new knowledge to the existing body of knowledge while confirming entrepreneurship education and entrepreneurial traits, skills and intention are positively related.

However, the paper has a number of limitations. The sample drawn from the population is limited to the University of Kelaniya and University of Sri Jayewardenepura. And future researchers can take undergraduates from all the five universities which is having entrepreneurship degree programs as their sample. And also, there are postgraduate degree programs on entrepreneurship. Future researchers can be selected them as their sample. Furthermore, in this study, quantitative method to analyze data and future researchers can use qualitative method in order to get the in depth ideas of respondents.

\section{References}

1. Driessen, M.P \& Zwart, P.S, 1999. The role of the entrepreneur in small business success. The Entrepreneurship Scan, Working paper, University of Groningen. 
2. Driessen, M., 2005. E-scan ondernemerstest's. Graveland. Entrepreneur Consultancy BV, the Netherlands.

3. Gibb, A., 2002. In pursuit of a new 'enterprise' and 'entrepreneurship' paradigm for learning: creative destruction, new values, new ways of doing things and new combinations of knowledge. International Journal of Management Reviews, 4(3), p. 233-269.

4. Hessel Oosterbeek, Mirjam van Praag \& Auke Ijssel, 2010. The impact of entrepreneurship education on entrepreneurship skills and motivation. European Economic Review, Volume 54, p. 442-454.

5. Lüthje, C \& Franke, N, 2003. The 'making' of an entrepreneur: testing a model of entrepreneurial intent among engineering students at MIT. R\&D Management, 33(2), p. 135-147.

6. M. Minniti \& M. Levesque, 2008. Rcecnt development in the economics of entrepreneurship. Journal of business venturing, Volume 23, pp. 603-612.

7. Merle Küttima, Marianne Kallastea, Urve Venesaar \& Aino Kiis, 2013. Entrepreneurship education at university level and students' entrepreneurial intentions. Contemporary Issues in Business, Management and Education, p. $658-668$.

8. Peterman, N.E \& Kennedy, J, 2003. Enterprise education: influencing students' perceptions of entrepreneurship. Entrepreneurship: Theory and Practice, pp. 129-144.

9. Thompson, E. R., 2009. Individual entrepreneurial intent: Construct clarification and development of an internationally reliable metric. Entrepreneurship Theory and Practice, Issue May, p. 669-694. 